\title{
Consumption Behavior of Economics Education Students Faculty of Economics, State University of Manado
}

\author{
Allen A. Ch. Manongko \\ Henry J.D. Tamboto \\ Sophia Pongoh \\ Sjeddie Rianne Watung \\ Faculty of Economics, State University of Manado \\ Email: allem.a.ch@gmail.com
}

\begin{abstract}
This study aims to determine the influence of financial literacy and social environmental factors on consumption behaviour of Economics Faculty of Economics students of Manado State University. The design of this study using the quantitative approach with survey method, with the number of samples is 67 students as respondents through proportionate stratified random sampling. The research instrument used questionnaire with a Likert scale which then tested the validity and reliability. Data analysis techniques include 1) Descriptive analysis; 2) Classical assumption test, and 3) Multiple linear regression analysis. The results showed: 1). There is a significant influence on financial literacy and student consumption behaviour, with the influence of financial literacy on student consumption behaviour of $54.4 \% ; 2$ ). There is a significant influence on social environment factor with student consumption behaviour, with the influence of social environment factor to student consumption behaviour equal to $37.5 \%$; and 3). There is the influence of variable of financial literacy and social environment factor to student consumption behaviour variable with a contribution equal to $78.6 \%$. Conclusion, partially or simultaneously financial literacy and social environmental factors have a significant effect on the consumption behaviour of students of Economics Education Faculty of Economics, State University of Manado.
\end{abstract}

Keywords: Consumption behaviour, financial literacy, social environment, students

The development of science, technology and informatics, has provided significant positive changes in human life but also gives a negative influence with the shift of norms and values in the midst of society. The existence of these developments, in terms of economics, provides acceleration for individuals in working, accessing and communicating. However, it must be remembered that in order to use it, the individual must remove something from his possessions. Ease gained from the above developments, the impact of increasing the expenditure (consumption) of a person's income.

Consumptive behaviour becomes fundamental in the current era of globalization. Sumartono (2002) indicates that consumers behave consumptively because of the following: Purchasing products for the lure of prizes; Buying the product because the packaging is attractive; Buy products for the sake of maintaining self-appearance and prestige; Buying products on price considerations (not on the basis of benefits or uses); Buying products just keeps a status symbol; Use the product because of the conformity to the model that advertises; and The emergence of an assessment that buying a product at an expensive price will generate a high degree of confidence; and Trying more than two similar products. 
Students as part of the community, not separated from a number of consumption activities. Even many among students there is a tendency to consume irrational and consumptive. A number of opinion research results indicate that the trend of consumption patterns of students less understanding of the concept of economics, finance, savings, and investment. This is illustrated by inappropriate consumption decisions. Attention and awareness of the value and benefits of consumption have not become important. More considerable is the social environment and lifestyle factors.

Academically, students are processed through learning in accordance with learning outcome. The success of the learning process can be shown from the ability of students in understanding, addressing and implementing a number of concepts or studies in his life both personally and environmentally. In addition, the ability of students in adjusting to the life of the campus is the key to success to achieve success undergraduate degree.

Student behaviour can be described through the pattern of thinking and lifestyle. The existence of thinking patterns can be translated into the views or perceptions of students in response to situations and conditions that require problem-solving. And lifestyles are often linked as lifestyles, looks, and trends, which are ultimately tied to consumptive culture.

In the understanding of consumptive, often related aspects of behaviour that in the economic concept has a negative tendency, meaning that consume something will be affected by income. As Keynes explains that consumption is influenced by disposable income, meaning that if disposable income rises then consumption also rises. It gives support to consumptive behaviour, which ultimately leads to the idea of consumerism. Consumerism is a consumption behaviour that is not directed, sometimes just following the prestige, uncontrolled, and just follow the trend.

Soegito (1996) in Parma (2007) argues that the consumption behaviour of Indonesian society is excessive compared to the peoples of Southeast Asia. This situation is seen from the low level of savings of Indonesian people compared to other countries such as Malaysia, the Philippines, and Singapore. This proves that the Indonesian people prefer to use the money to meet unimportant needs or live in a world of consumerism that is a necessary condition for the continuity of status and lifestyle. Consumptive behaviour is also understood as consumerism because people tend to search for and buy items that are considered the latest output but are not really needed. Conscious consumerism has become a culture and leads to a social disease that has the potential to create an individualistic and materialistic society, even leading to hedonism. This is marked by the existence of a group of people who actively consume luxury products as a prestige and honour just as the fulfilment of desire.

In interpreting the existence of students as the intellect, a number of ideas have clearly explained that the economic concept is directed so that every individual can think economically about every behaviour or action. Engel, reveals that consumptive behavioural actions are the actions of individuals who are directly involved in the business of obtaining, using and determining goods and services economically including decision-making processes.

In behaving economically, it is often a measure for each individual is how to manage finances. Managing finances is not an easy thing, because it is unaware that a number of existing phenomena show many individuals including students who are unable to apply 
financial knowledge in their lives. Financial knowledge or often referred to as financial literacy is a concept that describes how a person is able to competently apply knowledge of finance in meeting the needs and savings. Aaron and Isa (2009) find that the majority of Malaysian students have a low financial literacy, and this may lead to improving focus on the day-to-day financial decisions. Orton (2007) made it clear that financial literacy is an integral part of one's life because financial literacy is a useful tool for making informed financial decisions, but from experience in many countries still show relatively less. Byrne (2007) also found that low financial knowledge will lead to false financial plans, and cause biases in welfare achievement in the unproductive age.

Consumption behaviour is related to the individual's decision to buy or spend his income to earn something. The buying decision in the concept of consumer behaviour explains that decisions are influenced by customer trust, attitude and values, as well as various factors in the customer's social environment. Similarly, in the decision process of choosing goods or services is influenced by external factors and internal consumers.

The shift in consumer behaviour especially students is often caused by the adoption of new values that are positive or negative. The impact on most students regardless of parental income. The global lifestyle is reflected in the pattern of consumption behaviour concerning the number of goods and services needed. For the present, in purchasing an item, students who are teenagers in the age category tend not to ask for consideration from parents but they are more confident in their social friends. This kind of situation has become the habit of the students even if they have not earned their own income. The tendency leads to less effective consumption, ie consumption behaviour that no longer considers the economic condition of their parents, but they are more likely to follow fashion and trend, as well as the influence of television advertising and friends. Nowadays it is not a few encountered adolescent-style life hunt satisfaction and personal pleasure without regard to the economic condition of their parents who are looking for money for living expenses. In their minds only embedded pleasure and satisfaction, as well as glamour lifestyle. Currently, there is a tendency to behave like the above consumption, while the economic conditions of parents are not possible to provide facilities to meet the needs of excessive. Some even impose the will by using tuition to buy something because of prestige and to pursue satisfaction, when in fact the goods are not needed. This condition is often found in Economics Faculty of Economics students of Manado State University.

Based on the above explanations and considerations, this study specifically aims to determine and analyze the influence of financial literacy and social environmental factors on consumption behaviour of students Economics Education Faculty of Economics, State University of Manado.

\section{Consumptive behaviour}

Consumption is an expense for the purchase of final goods and services in order to obtain satisfaction or fulfil their needs. Consumption has a broad sense of the end goods and services needed to meet human needs. Goods and end services in question are goods and services that are ready to be consumed by consumers. Consumer goods consist of consumable consumables and which can be used more than once (Samuelson \& Nordhaus (1996); Nopirin (1993). 
To obtain, use or consume goods or services, every individual or society must issue something in some formulation derived from income (either permanent or temporary income). Dusenberry in Reksoprayitno (2000) argues that the consumption expenditure of a society is determined by the high income it has ever achieved. Revenue is reduced, consumers will not reduce much of their spending on consumption. To maintain a high level of consumption, forced to reduce the amount of saving. If income increases, then their consumption will also increase, but not too large increase. While saving will grow big by rapidly. This fact continues to meet the highest level of income we achieve. The point of consumption is always determined by income.

Nevertheless, today's rational consumption patterns are beginning to shift as technology develops into irrational consumption patterns. In the economic theory described a person in achieving his goal must always act rationally and then make decisions consistent with that goal. Irrational in question is an action in spending revenue to get goods or services that have not become a necessity. The irrational consumption pattern has moved into a consumptive pattern that gradually became a culture, resulting in the concept and understanding of consumerism.

Marcuse in Storey (2006) develops several arguments about consumption, indicating that consumerism aims to encourage false needs, which work as social controls (eg: People recognize themselves in their commodities, they find their souls in cars, devices hi-fi, luxury homes, beauty supplies and so on).

Consumption behaviour is a process and activity of individuals or groups related to the search, selection, purchase, use, and evaluation of products and services in order to meet the needs and desires. Simply put, consumer behaviour is an act that is directly involved in obtaining, using and consuming the product. Viewed from the economic activities of consumer behaviour is divided into rational and irrational consumption behaviour. In its development, today's consumption behaviour shows a fairly dynamic shift that leads to irrationality. This is reflected in the phenomenon and tendency to direct the current society to consumptive behaviour. Where buying behaviour is no longer based on value or rational use but has led to consuming something indefinitely where the individual is more concerned with the factors of desire than the needs and is characterized by the existence of luxury and excessive life.

In the theory of consumer behaviour, utility and satisfaction are important in explaining the concept of modern economy. Both terms are related to the value of use and satisfaction obtained by someone from consuming goods (Sukirno, 2006). There are basically two approaches used to explain consumer behaviour, namely the approach of marginal utility and indifference approach. In some assumptions about consumer behaviour associated with the theory of value use, the satisfaction obtained by a person in consuming a certain item. The higher the satisfaction obtained in consuming a certain item, the higher the useful value of the goods. Associated with the law of demand, if the price of a good rose then cateris paribus the number of consumers demanded on the goods will fall, and vice versa if the price is down then the amount demanded consumers will rise.

However, the shift in consumption value to consumptive is an irrational act caused by discontent and difference in decision making. Consumptive behaviour is one behaviour that can not be separated from the daily life of society. Enrico, et al (2014) argues that the emergence of consumptive behaviour knows no national borders, in 
which Indonesia is included. The facts show that most Indonesian people behave consumptively and love new goods, and are willing to spend some of their income to buy new products that are a trend (Pratama, 2013).

Various factors are the cause of the consumptive behaviour. Sumartono (2002), revealed that the emergence of consumptive behaviour especially among students caused by two things: internal factors are indicated through motivation, self-esteem, observation, learning process, personality and self-concept; and external factors indicated by culture, social class, social groups and references and family.

In the concept of consumer behaviour, Kotler and Armstrong (2007) explain that consumer buying behaviour is strongly influenced by cultural, social, personal, and psychological characteristics. Mangkunegara (2008) said consumer behaviour is the actions undertaken by individuals, groups or organizations related to the decisionmaking process in obtaining, using goods or services economically that can be influenced by the environment. Consumer behaviour concerns the decisions taken by a person in his competition and the determination to obtain and use goods and services. Consumers take a lot of buying decisions every day. Most large corporations examine consumer buying decisions in great detail to answer questions about what consumers buy, where they buy, how and how much they buy, and why they buy. Manufacturers can learn what consumers buy to find answers to questions about what they buy, where and how much, but to learn about the reasons for consumer behaviour is not easy, the answer is often hidden deep in the minds of consumers. Factors that affect why a person buys a product is to meet his needs and wants.

\section{Financial Literacy}

Some opinions are expressed about financial literacy. Lusardi \& Mitchaell (2007) defines financial literacy as the financial knowledge that has a goal to achieve prosperity. Orton (2007) made it clear that financial literacy is an integral part of one's life because financial literacy is a useful tool for making informed financial decisions, but from experience in many countries still show relatively less. According to the OECD, financial literacy is defined as the knowledge and understanding of financial concepts, abilities, motivations and beliefs in applying some organized knowledge and understanding in making effective decisions on the sphere of financial contexts to improve the financial welfare of communities and individuals and enable it to participate in economic life. According to Huston (2010), financial literacy is a part of the human capital that can be used in financial activities to increase the expected lifetime benefits of consumption. According to the Financial Services Authority, financial literacy is defined as a series of processes or activities to improve the knowledge, competence, skills of the consumers and the wider community so that they are able to better manage their finances (Financial Services Authority 2014). Chen and Volpe (1998) emphasized financial literacy on the ability to understand basic concepts of economics and finance, to how to apply them appropriately. Financial Literacy by Chen and Volpe (1998) is described in several aspects, namely general knowledge, savings, insurance and investments in accordance with the management of personal finances. Kharchenko (2011) states that financial literacy is a necessary numerical skill and an understanding of the basic economic concepts needed to educate in the decision to store and borrow.

There are several key elements of skill and knowledge of financial literacy. By Oseifuah (2010) and Wise (2013) suggests that: Mathematical knowledge and standard 
knowledge such as basic numerals and the ability to understand; Financial understanding of the nature and form of money, how money is used and the consequences of consumption decisions; Financial competencies such as understanding the key features of basic financial services, attitudes in using money and savings, understanding financial records and realizing the importance of reading and maintaining them; Be aware of the risks associated with financial products, and understand the relationship between risk and income; and Financial responsibility, namely the ability to make informed decisions about financial issues, knowing the rights and responsibilities of consumers, the ability, and the trust to seek help when something goes wrong.

\section{Social environmental factors}

One of the factors that influence consumer behaviour is the social environment. The social environment is related to the influence of others on consumers in the consumption situation (Belk, 1975). Fatchur Rohman (2008) argues that consumers can relate directly to others doing activities. The social environment consists of reference groups, family roles and social status). The environment in which individuals interact. The environment has several aspects such as social attitudes, psychological attitude, spiritual attitude and so forth (Bintarto \& Surastopo, 1991). The influence of the social environment is not only from the family but also from the neighbourhood because around the place of social interaction occurs between students and the people around him. The social environment has a positive effect on consumption behaviour. This implies that high-low influence of the family environment, residence environment, and existence in the group will affect the pattern of consumption behaviour. The highest contribution of social environmental indicators is group existence, while the lowest contribution of social environment indicator is the residence environment. Thus, the environment in which a person interacts also influences consumption behaviour that occurs among students and students.

\section{Hypothesis}

The hypothesis in this research is 1). Partially, financial literacy and social environmental factors, have an influence on consumption behaviour of Economics Education Students Faculty of Economics, State University of Manado. 2). Simultaneously, financial literacy and social environment factors, have an influence on the consumption behaviour of students of Economic Education Faculty of Economics, State University of Manado.

\section{METHODS}

The design of this research using the quantitative approach with survey method, which aims to find out how much financial literacy and social environmental factors affect the consumption behaviour of economic education students Faculty of Economics, State University of Manado well. The population in this study is all students majoring in economic education with a concentration in active accounting education (enrolled) academic year 2016/2017 semester of 140 students (4 classes). With the total sample is 67 students as respondents through proportionate stratified random sampling.

The research variables include: independent variables are: financial literacy (X1). Financial literacy is defined as knowledge and understanding of financial concepts in an effort to achieve prosperity. Indicators of financial literacy are: general knowledge of finance, savings, insurance and investment; Social environmental factors (X2), defined as 
individual places (students) interact that provide value. Indicator: social class, reference group, and family. Dependent variable (Y) is student consumption behaviour. Consumption behaviour is a tendency to consume goods or services in excess or no limit and more concerned with the desire factor than the needs. Indicators: fulfilment of needs according to intensity, application of economic principles in consumption, consumption motives, priority scale in consumption, and selective in consumption.

The research instrument used questionnaires, with a list of closed questions and statements. Measurement scale using Likert scale (with 5 alternative answers). Instrument testing with validity and reliability test (SPSS 16 program application). Validity test by comparing correlation index of product moment person with $5 \%$ significance level with a critical value, considered valid if the significant value of $\mathrm{t}(\operatorname{sig} \mathrm{t})$ from Pearson correlation results in less than 0.05 (Sugiyono, 2007). Test reliability using alpha Cronbach. Expressed reliably if the value of $\mathrm{r} 11 \geq 0.6$ and if the value of $\mathrm{r} 11 \leq 0.6$ otherwise not reliable (Sugiyono, 2013). The test results of validity and reliability, shown as follows:

\section{Test results validity}

The result of validity test on 25 items obtained the range of values is 0.275 up to 0.775 , the result is greater than the critical value of 0.244 , with the sig. $<0.05$. This means that the entire item meets the valid requirements.

\section{Reliability test results}

Reliability test results show that the three variables have a value of $\mathrm{C} \alpha \geq 0.6$, with the acquisition of $\mathrm{X} 1=0.720 ; \mathrm{X} 2=0.862$; and $\mathrm{Y}=0.763$, meaning the three variables are reliable.

\section{Data Analysis Technique}

Data analysis techniques include: 1) Descriptive analysis includes: mean and standard deviation; 2) Test requirements, and 3) Multiple linear regression analysis.

\section{RESULT AND DISCUSSION}

Descriptive Statistics Results

Table 1. Descriptive Statistics

\begin{tabular}{|l|r|r|r|}
\hline & Mean & Std. Deviation & N \\
\hline Student Consumption Behavior & 38.4478 & 5.86020 & 67 \\
Financial Literacy & 43.3731 & 5.13112 & 67 \\
Social Environment Factor & 15.8358 & 2.37153 & 67 \\
\hline
\end{tabular}


Classic Assumption Test Results

Normality test

Table. One-Sample Kolmogorov-Smirnov Test

\begin{tabular}{|ll|r|r|r|}
\hline & $\begin{array}{c}\text { Financial } \\
\text { Literacy }\end{array}$ & $\begin{array}{c}\text { Social } \\
\text { Environment } \\
\text { Factor }\end{array}$ & $\begin{array}{c}\text { Student } \\
\text { Consumption } \\
\text { Behavior }\end{array}$ \\
\hline $\mathrm{N}$ & & 67 & 67 & 67 \\
Normal Parameters & Mean & 43.3731 & 15.8358 & 38.4478 \\
& Std. Deviation & 5.13112 & 2.37153 & 5.86020 \\
Most Extreme & Absolute & .107 & .168 & .126 \\
Differences & Positive & .107 & .099 & .102 \\
& Negative & -.106 & -.168 & -.126 \\
Kolmogorov-Smirnov Z & .872 & 1.377 & 1.034 \\
Asymp. Sig. (2-tailed) & .432 & .045 & .236 \\
\hline
\end{tabular}

a. Test distribution is Normal.

Kolmogorov-Smirnov test results using the rule value: If the value of sig $>0.05$, then the data is normally distributed, and if the sig value $<0.05$, then the data is not abnormal distribution. Under these conditions, the test results in Table 4 indicate that the distribution test is normal.

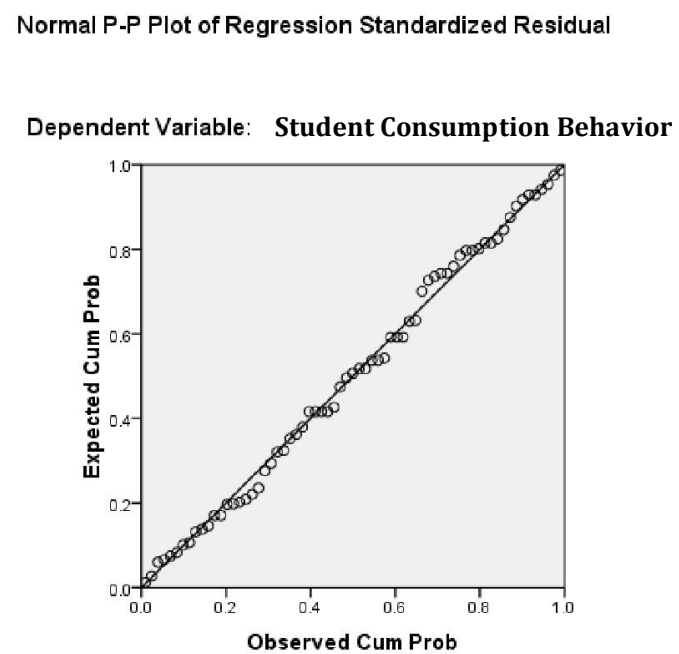

Gambar 1. Normal P-P Plot

Similarly in the Normal P-P Plot results. The normality assumption is that the residual regression model is normally distributed. Normally distributed criteria or not, with the 'Normal P-P Plot' approach can be seen from the distribution of the points in the picture beside. From the distribution of the points in the figure above, it shows that the dots are scattered close or close in a straight line (diagonal), meaning that the residual data is normally distributed.

\section{Linearity Test}


This linearity test using Compare Means test from SPSS version 16 for windows. Based on the analysis that has been done, it is known that: the value of F is 122.563 with the sig. $0.000 \mathrm{a}$. Thus, it is concluded that independent variables simultaneously choose linear relationships.

\section{Multicollinearity Test}

Table 3. Coefficients ${ }^{\mathrm{a}}$

\begin{tabular}{|c|c|c|}
\hline \multirow[b]{2}{*}{ Model } & \multicolumn{2}{|c|}{ Collinearity Statistics } \\
\hline & Tolerance & VIF \\
\hline Financial Literacy & .242 & 4.128 \\
\hline Social Environment Factor & .242 & 4.128 \\
\hline
\end{tabular}

a. Dependent Variabel: Student Consumption Behavior

Multicollinearity test results (output SPSS 16), in Collinearity Statistics column. As the criterion not the occurrence of multicollinearity VIF value $<10$. Based on the results obtained, indicating that the VIF value for the financial literacy variable and social environment factor is 4.128 , with a tolerance of each variable is 0.242 , indicating that the VIF value $<10$, it can be concluded that multicollinearity occurs in the three independent variables.

\section{Autocorrelation Test}

Table 4. Model of Summary ${ }^{b}$

\begin{tabular}{|c|c|}
\hline Model & Durbin-Watson \\
\hline 1 & $2.327^{\mathrm{a}}$ \\
\hline
\end{tabular}

a. Predictors: (Constant), Social Environment Factors, Financial Literacy

b. Dependent Variabel: Student Consumption Behavior

Test autocorrelation can be seen in table Model Summary in column DurbinWatson. The Durbin-Watson (DW) result is 2,327, meaning that this value is between the two du $(1,731)$ and $4 d u(2,481)$. Based on the obtained value concluded that this regression model does not occur autocorrelation

Heteroscedasticity Test 
Table 5. Correlations

\begin{tabular}{|c|c|c|c|c|c|c|}
\hline & & & $\begin{array}{l}\text { Financial } \\
\text { Literacy }\end{array}$ & $\begin{array}{c}\text { Social } \\
\text { Environment } \\
\text { Factor }\end{array}$ & $\begin{array}{c}\text { Student } \\
\text { Consumptio } \\
\mathrm{n} \text { Behavior }\end{array}$ & $\begin{array}{l}\text { Unstandardize } \\
\text { d Residual }\end{array}$ \\
\hline \multirow[t]{12}{*}{$\begin{array}{l}\text { Spearma } \\
\text { n's rho }\end{array}$} & \multirow[t]{3}{*}{ Financial Literacy } & $\begin{array}{l}\text { Correlation } \\
\text { Coefficient }\end{array}$ & 1.000 & $.786^{* *}$ & $.790^{* *}$ & -.084 \\
\hline & & Sig. (2-tailed) & & .000 & .000 & .502 \\
\hline & & $\mathrm{N}$ & 67 & 67 & 67 & 67 \\
\hline & \multirow[t]{3}{*}{$\begin{array}{l}\text { Social Environment } \\
\text { Factor }\end{array}$} & $\begin{array}{l}\text { Correlation } \\
\text { Coefficient }\end{array}$ & $.786^{* *}$ & 1.000 & $.744^{* *}$ & -.058 \\
\hline & & Sig. (2-tailed) & .000 & & .000 & .642 \\
\hline & & $\mathrm{N}$ & 67 & 67 & 67 & 67 \\
\hline & \multirow{3}{*}{$\begin{array}{l}\text { Student } \\
\text { Consumption } \\
\text { Behavior }\end{array}$} & $\begin{array}{l}\text { Correlation } \\
\text { Coefficient }\end{array}$ & $.790^{* *}$ & $.744^{* *}$ & 1.000 & $.477^{* *}$ \\
\hline & & Sig. (2-tailed) & .000 & .000 & & .000 \\
\hline & & $\mathrm{N}$ & 67 & 67 & 67 & 67 \\
\hline & \multirow[t]{3}{*}{$\begin{array}{l}\text { Unstandardized } \\
\text { Residual }\end{array}$} & $\begin{array}{l}\text { Correlation } \\
\text { Coefficient }\end{array}$ & -.084 & -.058 & $.477^{* *}$ & 1.000 \\
\hline & & Sig. (2-tailed) & .502 & .642 & .000 & \\
\hline & & $\mathrm{N}$ & 67 & 67 & 67 & 67 \\
\hline
\end{tabular}

**. Correlation is significant at the 0.01 level (2-tailed).

In the residual column, it can be seen that the correlation coefficient value is a low or significant value (Sig. (2-tailed)) each independent variable above 5\%, meaning that each independent variable has no relation with its residual. Thus, it can be concluded that there are no heteroskedasticity on multiple linear regression models obtained.

\section{Results of Multiple Linear Regression Analysis}

Based on the results of multiple linear regression analysis using SPSS.16 software, the results obtained in the table below:

Table 6. Coefficients ${ }^{a}$

\begin{tabular}{|ll|r|r|r|r|r|}
\hline \multirow{2}{*}{ Model } & \multicolumn{2}{|c|}{$\begin{array}{c}\text { Standardized } \\
\text { Unstandardized Coefficients }\end{array}$} & \multicolumn{2}{c|}{ Coefficients } & \\
\cline { 2 - 5 } & \multicolumn{1}{|c|}{ B } & Std. Error & \multicolumn{1}{c|}{ Beta } & \multicolumn{1}{c|}{ Sig. } \\
\hline 1 & (Constant) & -3.207 & 2.874 & & -1.116 & .269 \\
& Financial Literacy & .622 & .132 & .544 & 4.712 & .000 \\
& Social Environment Factor & .927 & .286 & .375 & 3.247 & .002 \\
\hline
\end{tabular}

a. Dependent Variabel: Student Consumption Behavior

Results of the table above obtained the regression equation is:

$\mathrm{Y}=-3.207+0.622 \mathrm{X} 1+0.927 \mathrm{X} 2+\mathrm{e}$

The multiple linear regression equations show that the independent variable (financial literacy and social environment factor) analyzed give positive influence to the dependent variable (student consumption behaviour). 
The model of this regression equation can be explained as follows: 1 ). The constant value of -3.207 can be interpreted that if the variable of financial literacy and social environment factor, considered fixed or not change, then the behaviour of student consumption amounted to $-3.207 ; 2$ ). Financial Literacy (X1) has a regression coefficient of 0.622 , this means that any increase in variable financial literacy of one unit will increase the behaviour of student consumption by 0.622 assuming another variable is fixed. The positive sign indicates a direct relationship between financial literacy and student consumption behaviour; 3). The social environment factor (X2) has a regression coefficient of 0.927 , this means that any increase of social environment factor variable of one unit will increase student consumption behaviour by 0.927 with the assumption that another variable is fixed. A positive sign indicates a direct relationship between social environmental factors and student consumption behaviour.

\section{Hypothesis testing}

Partial Test (t-test)

Terms:

H0: b1, b2 = 0, meaning that variation of independent variable can explain the dependent variable and there is influence between the two variables tested.

Ha: $b 1, b 2 \neq 0$, meaning that the variation of the independent variable cannot explain the dependent variable and there is no influence between the two variables tested.

Testing is done through t-test by comparing tcalc with ttable at $\alpha 0,05$. If the calculation results show: 1). tcount $\geq$ ttable, then Ho is rejected and Ha accepted, meaning the variation of independent variables can explain the dependent variable and there is influence between the two variables tested. 2). tcount <ttabel, then Ho accepted and Ha rejected, meaning the variation of independent variable cannot explain dependent variable and there is no influence between two variables tested.

Based on table 8, the partial test results (t-test) can be explained as follows: 1). The calculation results obtained tcount of 4.712> ttable of 1.980, then Ho is rejected and H1 accepted, which means that there is an influence on financial literacy and student consumption behaviour. The amount of influence of financial literacy on student consumption behaviour is 0.544 or $54.4 \%$ (Standardized Coefficients) at a significant level of $0.000<0.05$, so it can be stated significant; 2). The calculation results obtained tcount of 3.247> ttable of 1.980, then Ho is rejected and $\mathrm{H} 1$ accepted, which means that there is an influence on social environmental factors with student consumption behaviour. The magnitude of the influence of social environmental factors on the consumption behaviour of students of 0.375 or $37.5 \%$ (Standardized Coefficients) at a significant level of $0.002<0.05$, so it can be stated significant. 


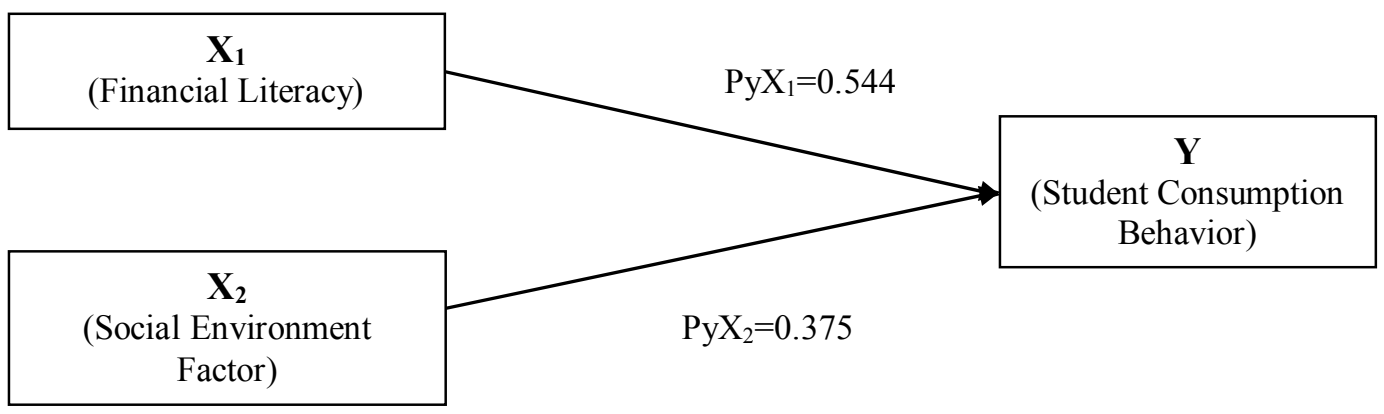

Figure 2. Influence between Variables

\section{Simultaneous Test (F Test)}

Terms:

The hypothesis formula using $F$ test is Ho: $b 1, b 2=0, H a: b 1, b 2 \neq 0$, Testing is done by $F$ test by comparing $\mathrm{F}(\mathrm{Fh})$ with Ftable $(\mathrm{Ft})$ at $=0,05$. If the result of the calculation shows: 1). $\mathrm{Fh}>\mathrm{Ft}$, then $\mathrm{Ho}$ is rejected and $\mathrm{Ha}$ accepted, and 2). $\mathrm{Fh}<\mathrm{Ft}$, then Ho accepted and $\mathrm{Ha}$ rejected. F test is done to know the effect simultaneously between independent variable with the dependent variable. F test results can be seen in ANOVAb table below:

Table 7. ANOVA

\begin{tabular}{|ll|r|r|r|r|r|}
\hline Model & & Sum of Squares & df & Mean Square & F & \multicolumn{1}{c|}{ Sig. } \\
\hline 1 & Regression & 1797.308 & 2 & 898.654 & 122.563 & $.000^{\mathrm{a}}$ \\
& Residual & 469.259 & 64 & 7.332 & & \\
& Total & 2266.567 & 66 & & & \\
\hline
\end{tabular}

a. Predictors: (Constant), Faktor Lingkungan Sosial, Literasi Finansial

b. Dependent Variabel: Perilaku Konsumsi Mahasiswa

The results of table 2 of ANOVAb shows that: Fcount value $(122,563)>$ Ftable (2.44) and Sig value of research (0.000a) < value of significant level (0.05). This means that the alternative hypothesis (Ha / H1) is accepted and the null hypothesis (Ho) is rejected, so it can be concluded that the estimated regression model is feasible, with the statement that the financial literacy variable and the social environmental factors simultaneously significantly influence the consumption behavior of the students of Economic Education Faculty of Economics, Manado State University.

\section{Coefficient of Determination}

The coefficient of determination in this study aims to explain the influence of independent variables (loyalty, competence, and work environment) to the dependent variable (employee performance) simultaneously. To know the amount of contribution simultaneously, based on Adjusted R Square value in the summary model table below: 
Table 8. Model of Summaryb

\begin{tabular}{|c|c|c|c|c|c|c|c|c|c|}
\hline \multirow[b]{2}{*}{$\begin{array}{l}\text { Mode } \\
1\end{array}$} & \multirow[b]{2}{*}{$\mathrm{R}$} & \multirow[b]{2}{*}{ R Square } & \multirow[b]{2}{*}{$\begin{array}{l}\text { Adjusted R } \\
\text { Square }\end{array}$} & \multirow[b]{2}{*}{$\begin{array}{l}\text { Std. Error of } \\
\text { the Estimate }\end{array}$} & \multicolumn{5}{|c|}{ Change Statistics } \\
\hline & & & & & $\begin{array}{c}\text { R Square } \\
\text { Change }\end{array}$ & F Change & dfl & $\mathrm{df} 2$ & $\begin{array}{l}\text { Sig. F } \\
\text { Change }\end{array}$ \\
\hline 1 & $.890^{\mathrm{a}}$ & .793 & .786 & 2.70780 & .793 & 122.563 & 2 & 64 & .000 \\
\hline
\end{tabular}

a. Predictors: (Constant), Faktor Lingkungan Sosial, Literasi Finansial

b. Dependent Variabel: Perilaku Konsumsi Mahasiswa

Based on Summary Model table, the Adjusted R-Square value is 0.786. This shows that the proportion of influence of financial literacy variable and social environment factor to student consumption behaviour variable is $78.6 \%$. This means that financial literacy and social environmental factors simultaneously have a significant effect on consumption behaviour of Economics Faculty of Economics students of Manado State University by $78.6 \%$ while $21.4 \%(100 \%-78.6 \%)$ is influenced by other variables that are not in this multiple linear regression models.

The influence of financial literacy and social environment factors on consumption behaviour

The research findings prove that the financial literacy and social environment factors simultaneously have a significant and positive influence on consumption behaviour of the students of Economics Education Faculty of Economics, Manado State University. This is indicated by the Fcount Value $(122,563)>$ Ftable $(2.44)$ and the Sig value of the research $(0.000 \mathrm{a})$ <significant level value $(0.05)$. This means that the estimated regression model is feasible, with a simultaneous contribution of $83.5 \%$. This is in accordance with the opinion of Lusardi \& Mitchell (2010), Chen and Volpe (2002), Kotler and Keller (2006), Inderjeet Sethi and AS Chawla (2014), Nayeem, Tahmid (2012) influenced by factors in this research. Empirical results describe that financial literacy and social factors give a real contribution to consumer consumption behaviour. This means that with consideration of the opinion empirically proves that the higher the value obtained by the two independent variables, will also increase the value of consumption behaviour of students Economics Education Faculty of Economics, the State University of Manado in behaving.

\section{The influence of financial literacy on consumption behaviour}

The findings of the study prove that the financial literacy has a significant and positive effect on consumption behaviour of Economics Faculty of Economics students of Manado State University. This is indicated by tcount of $4,712>$ ttable of 1980 , with the influence of financial literacy on student consumption behaviour of 0.544 or $54.4 \%$ at a significant level of $0.000<0.05$, so it can be stated significant. The results are in accordance with the opinion of Lusardi \& Mitchell (2010), Chen and Volpe (2002), Lutfi \& Iramani (2008), which revealed that the economic and financial concept of knowledge gives positive value to consumer behaviour in taking a stunt to shop or buy. This means that the higher the value of financial literacy will also increase the consumption behaviour of students Economics Education Faculty of Economics, the State University of Manado in considering the behaviour.

The influence of social environmental factors on consumption behaviour 
The findings of the study prove that the social environment has a significant and positive impact on the consumption behaviour of students of Economics Education Faculty of Economics, State University of Manado. This is indicated by t count of 3.247> ttable of 1.980, with the magnitude of social environmental impact on student consumption behaviour of 0.375 or $37.5 \%$ at a significant level of $0.002<0.05$, so it can be stated significant. The results are in accordance with the opinion of Lamb (2001), Kotler and Keller (2009), which revealed that social environmental factors have a significant effect on the consumption behaviour of individuals or communities in spending their income. This means that the higher the value of the social environment will also increase the consumption behaviour of students Economics Education Faculty of Economics, State University of Manado.

\section{CONCLUSION AND SUGGESTION}

\section{Conclusion}

Based on the results of the analysis and discussion, the conclusions of this study are as follows: Financial Literacy and social environmental factors together have a relationship, influence, and contribute positively to the consumption behaviour of students Economics Education Faculty of Economics, State University of Manado. Financial Literacy has an influence and contributes positively to the consumption behaviour of students Economics Education Faculty of Economics, State University of Manado. Social environmental factors have an influence and contribute positively to the consumption behaviour of students of Economic Education Faculty of Economics, State University of Manado. Based on the findings of this study have the following implications: Both exogenous variables have the ability to explain student consumption behaviour. This suggests that financial literacy and social environmental factors can provide value to students and consumers in general in behaving in consumption. Consumption behaviour is a series of activities in the form of actions and decision-making process of consumption activities. The two variables that explain consumption behaviour have provided changes for students in behaving, so that both understanding knowledge in managing finances, social life can be considered in the concept of consumer behaviour.

\section{Suggestion}

Based on the results of this study, some recommendations for future research, namely: This study still focuses on students who are heterogeneous in a social environment as well as knowledge. So to generalize in a social and cultural environment of society, in general, is still too early. There are a number of variables that have not been included in this study, especially psychological and physiological factors, as well as cultures that are believed to have a strong influence on student consumption behaviour. In collecting data through questionnaire and quantitative approach in analyzing, it is believed still not able to answer the problem of this research. For that matter, it is necessary to do research with a qualitative approach. 


\section{REFERENCES}

Byrne, A. 2007. Employee saving and investment decisions in defined contribution pension plans: survey evidence from the U.K. Financial Services Review 16 (2007) $19-40$

Chen, Haiyang and Volpe, Ronald P. 2002. Gender Differences in Personal Financial Literacy Among College Students. Financial Services Review. Vol 11. Pp 289-307.

Enrico, A., Aron, R., \& Oktavia, W. (2014). The factors that influenced consumptive behaviour: A survey of university students in Jakarta. International Journal of Scientific and Research Publications, 4(1), 1-5

Harun, R. Ibrahim, D.\& Isa, Z.M. (2009) "A Study on Financial Literacy of Malaysian Degree Students”. Cross-cultural Communication ISSN 1712-8358, 5(4), 51-59.

Huston, Sandra J. 2010. Measuring Financial Literacy. The Journal of Consumer Affairs, Volume 44 No. 2. Hal. 296-315

Inderjeet Sethi dan AS Chawla. Journal of Marketing Management. American Research Institute for Policy Department, USA. March 2014. Vol. 2. No 1. Pp. 97-110.

Kotler, P. dan G, Armstrong. 2007. Dasar-dasar Pemasaran. Jilid 1. Edisi Tujuh. Penerbit Prentice Hall-Inc. Jakarta

Lamb, H. 2001. Pemasaran. Edisi Pertama. Salemba Empat. Jakarta

Lusardi, A \& Mitchell, O. S. 2010. Financial Literacy Among The Young. The Journal of Consumer Affairs. Vol 44 No. 2. Pp. 358-380.

Lutfi \& Iramani. 2008. Financial Literacy Among University Student and Its Implications to The Teaching Method. Jurnal Ekonomi Bisnis dan Akuntansi Ventura. Vol. 11 Pp 2. Mangkunegara P. A., 2008. Manajemen Sumber Daya Manusia. Cetakan ke-3. Bandung: PT. Nayeem, Tahmid. Cultural Influences on Consumer Behaviour. International Journal ofBusiness and Management. Canada: Canadian Center of Science and Education. Vol.7, No. 21;2012.

Nopirin, 1993. Ekonomi Moneter. Edisi 4. Cetakan Kedua, Penerbit BPFE, Yogyakarta

Orton, L. 2007. Financial Literacy: Lessons from International Experience. CPRN Research Report September 2007

Oseifuah, Emmanuel Kojo. 2010. Financial Literacy and Youth Entrepreneurship in South Africa. Thohoyandou: Department of Accounting and Auditing University of Venda

Otoritas Jasa Keuangan. 2014. Strategi Nasional Literasi Keuangan Indonesia. Jakarta.

Pratama, A. F. (5 Desember 2013). Ekonomi Indonesia ditopang pola konsumtif masyarakat. Tribun News. Diakses dari http://www.tribunnews.com/ bisnis/2013/12/05/ekonomi-indonesia-ditopang-pola-konsumtif-masyarakat 
Reksoprayitno, Soediyono, 2000. Ekonomi Makro, Yogyakarta: Penerbit BPFE

Samuelson, Paul A. Dan Nordhaus William D. 1996. Makro Ekonomi. Edisi ke- 17. Cetakan ketiga. Jakarta: Erlangga

Storey, John. 2006. Cultural Studies dan Kajian Budaya Pop. Yogyakarta: Jalasutra

Sugiyono, 2013. Metode Penelitian Pendidikan: Pendekatan Kuantitatif, Kualitatif, dan $R \& D$. Bandung: Alfabeta.

Sukirno, Sadono. 2006. Mikro Ekonomi Teori Pengantar. Jakarta: Rajagrafindo Persada

Sumartono. 2002. Terperangkap dalam Iklan: Meneropong Imbas Pesan Iklan Televisi. Bandung: Alfabeta.

Wise, Sean. 2013. The Impact of Financial Literacy on New Venture Survival. International Journal of Business and Management, Volume 8, No. 23 